\title{
Nanotechnology-Based Delivery Systems: Highlights in Agricultural Applications
}

\author{
Jhones L. de Oliveira ${ }^{a}$, \\ Estefânia V.R. Campos ${ }^{a}$, Marcela C. Camara ${ }^{a}$, \\ Lucas B. de Carvalho ${ }^{\text {, }}$ Renata A. Monteiro ${ }^{a}$, \\ Renata de Lima ${ }^{\mathrm{b}}$ and Leonardo F. Fraceto*a \\ ${ }^{a}$ Laboratory of Environmental Nanotechnology \\ São Paulo State University (UNESP) \\ 511 Avenida Três de Março, Sorocaba, \\ São Paulo, 18087-180, Brazil \\ ${ }^{b}$ University of Sorocaba \\ km 92.5 Rodovia Raposo Tavares, \\ Sorocaba, São Paulo, 18023-000, Brazil
}

Received 19.02.2019, received in revised form 21.05.2019, accepted 04.06.2019

\begin{abstract}
Due to the excessive use of chemical agents in agriculture, numerous problems have arisen, such as contamination of the environment, intoxication of non-target organisms and the development of resistance mechanisms by pests. To overcome these challenges, several sustainable technological approaches are being explored, and nanotechnology is one of them. This review aims to provide insights into the use of nanotechnology related to the agricultural sector. Articles were selected using the Web of Science and Science Direct databases; more than 50 manuscripts between 2015 and 2019 were reviewed. This review includes systems based on nanotechnology, in particular, for the sustained release of active ingredients for pest control, nutrition and plant growth. Nanoparticlebased formulations have great potential to increase agricultural productivity and reduce health and environmental impacts. However, there are certain technological challenges that must be addressed to allow the adoption of this technology for wider use in agri-food production.
\end{abstract}

Keywords: nanotechnology-based delivery systems, sustained release, nanoparticles, sustainable agriculture, herbicides, insecticides, hormones and nutrients.

(C) Siberian Federal University. All rights reserved

This work is licensed under a Creative Commons Attribution-NonCommercial 4.0 International License (CC BY-NC 4.0).

* Corresponding author E-mail address: leonardo.fraceto@unesp.br

ORCID: 0000-0002-9664-0349 (Oliveira J.L. de); 0000-0002-9420-7461 (Campos E.V.R.); 0000-0002-3630-3455 (Camara M.C.); 0000-0002-1956-0580 (Carvalho L.B. de); 0000-0002-4118-2491 (Monteiro R.A.); 0000-0001-8712-1144 (Lima R. de); $\overline{0000-0002-2827-2038}$ (Fraceto L.F.) 
Citation: Oliveira J.L. de, Campos E.V.R., Camara M.C., Carvalho L.B. de, Monteiro R.A., Lima R. de, Fraceto L.F. Nanotechnology-based delivery systems: highlights in agricultural applications. J. Sib. Fed. Univ. Biol., 2019, 12(3), 311-328. DOI: $10.17516 / 1997-1389-0305$.

\title{
Основные характеристики
}

наноразмерных систем доставки,

предназначенных для применения

в сельском хозяйстве

\author{
Дж.Л. де Оливейра ${ }^{a}$, Э.В.Р. Кампоса \\ М.К. Камара ${ }^{\text {a }}$ Л.Б. де Карвалью \\ Р.А. Монтейро ${ }^{\mathrm{a}}$ Р. де Лима ${ }^{\tilde{\sigma}}$, Л.Ф. Фрасето \\ ${ }^{a}$ Государственный университет Сан-Паулу (UNESP) \\ Институт науки и техники Сорокабы (ICTS) \\ Бразилия, 18087-180, Сан-Паулу, Сорокаба, \\ Авенида Трес де Мари, 511 \\ ${ }^{6}$ Университет Сорокабы \\ Бразилия, 18023-000, Сан-Паулу, Сорокаба, \\ Родовия Рапосо Таварес, км 92,5
}

\begin{abstract}
Чрезмерное использование химических веществ в сельском хозяйстве привело к возникновению множества проблем, в частности загрязнению окружающей среды, токсическому воздействию на организмы, не являющихся мишенями, а также к развитию механизмов устойчивости у вредителей. Для преодоления этих вызовов изучается ряд устойчивых технологических подходов, одним из которых выступает нанотехнология. Данный обзор призван дать представление об использовании нанотехнологий применительно к сельскохозяйственному сектору. Статьи отбирали с помощью баз данных Web of Science u Science Direct; было проанализировано более 50 рукописей за период с 2015 по 2019 год. Обзор описывает нанотехнологические системы, в частности, для замедленного высвобождения активных ингредиентов для борьбы с вредителями, для питания и роста растений. Препараты на основе наночастии имеют большой потенциал для повышения продуктивности сельского хозяйства и снижения воздействия на здоровье и окружаюшую среду. Тем не менее остаются определенные технологические проблемы, которые должны быть решены для более широкого использования этих технологий в производстве продуктов питания.
\end{abstract}

Ключевые слова: наноразмерные системы доставки, замедленное высвобождение, наночастиць, устойчивое сельское хозяйство, гербициды, инсектициды, гормоны и питательные вещества. 


\section{Introduction}

Agribusiness has proven to be one of the most important sectors of the world economy. The growing demand for food caused by population growth, as well as by the scarcity of productive regions, puts pressure on this sector (Bruinsma, 2017). The so-called green revolution has led to great progress in agribusiness. However, it was based mainly on the use of agrochemicals and fertilizers and the mechanization of production. This resulted in poor management practices, in particular, excessive use of agrochemicals, which caused environmental contamination. With the growing concern of the harm caused by chemical methods of crop protection, it is of paramount interest to make considerable technological, economic and commercial advances in environmentally friendly agricultural technologies that will allow for gradual improvement in the sector (Shiva, 2016).

In this context, applications of nanotechnology in the agricultural and food sectors deserve special attention. Nanotechnology is viewed as a breakthrough approached "in basic research, development of technologies and new materials production" (He et al., 2019). Nanotechnology has great potential to revolutionize agriculture and food systems throughout the agricultural chain. It is currently an important tool for increasing agricultural productivity that complements conventional agriculture technologies. Unlike the conventional delivery of agrochemicals, which require several applications to obtain the effective dose, nanotechnology-based delivery systems are able to perform a sustained release of active compounds in the dosing interval between the minimum effective concentration and maximum safe concentration (Fig. 1). Thus, nanotechnology-based delivery systems reduce the amount of active compounds required for a biological response and decrease environmental contamination risks, energy consumption and labour costs. Nanotechnology can provide greater safety for agricultural crops and for nontarget organisms, such as pollinators (Fraceto et al., 2016; Kremer, 2019; Shukla et al., 2019).

Therefore, promoting the growth of food production and thereby contributing to the development of sustainable agriculture

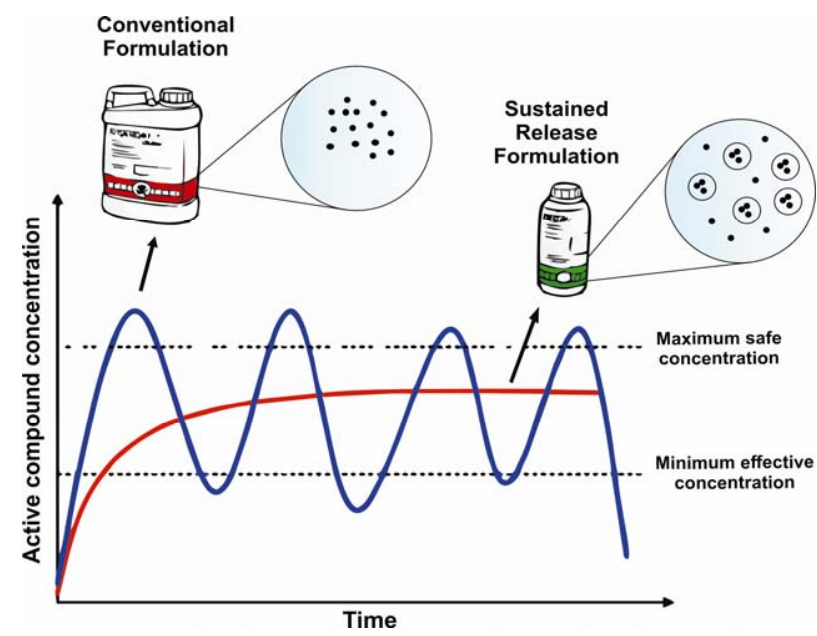

Fig. 1. Schematic representation of a conventional system and a sustained release system for agricultural applications. The effectiveness and concentration of an active compound in a conventional system decreases as a function of time, requiring new applications. The sustained release system, however, maintains the concentration of the active compound in an effective range of action

$$
-313-
$$


and improving food security investments in developing nanotechnology in agriculture is important.

\section{Nanoparticle-based formulations for agricultural applications}

Agricultural formulations are based mainly on active components that act against different types of pests and diseases (insects, fungi, rodents, plants, etc.). However, in recent years, the agricultural market has been increasingly interested in formulations that affect crop growth and development (hormones and nutrients). Researchers have tried to address these demands using nanotechnology in the agricultural sector. Due to the growing concern about environmental impacts, molecules and compounds derived from natural matrices are also being widely studied (Fig. 2). Below, we outline some advances in nanocarrier systems for active ingredients used in agriculture.

\section{Herbicides}

Herbicides are a class of substances that belong to agricultural pesticides and are specifically used to control weeds. Weeds are considered to be invasive plants because they compete with cultivated plants for light, moisture and nutrients. In addition, weed species possess great rusticity, resistance to pests and a capacity to produce large numbers of seeds, which increases their propagation rate (Cobb and Reade, 2010; Zimdahl, 2018). Herbicides are widely used because of their numerous advantages, such as high speed of action, flexibility of treatment schedule and suitability for application on large areas. Herbicides can be classified according to their selectivity, chemical structure, mechanism of action and mode of application (pre- or postemergence pesticides) (Prosser et al., 2016). Table 1 presents a number of papers on the use of nanotechnology-based carrier systems for herbicidal compound applications.

Maruyama et al. (2016) used combinations of imazapyr and imazapic encapsulated in chitosan-based nanoparticles (chitosan/alginate, CS/ALG, and chitosan/tripolyphosphate, $\mathrm{CS} / \mathrm{TPP}$ ) to control weeds. According to the authors, the encapsulation efficiency for the CS/ALG and CS/TPP nanoparticles was

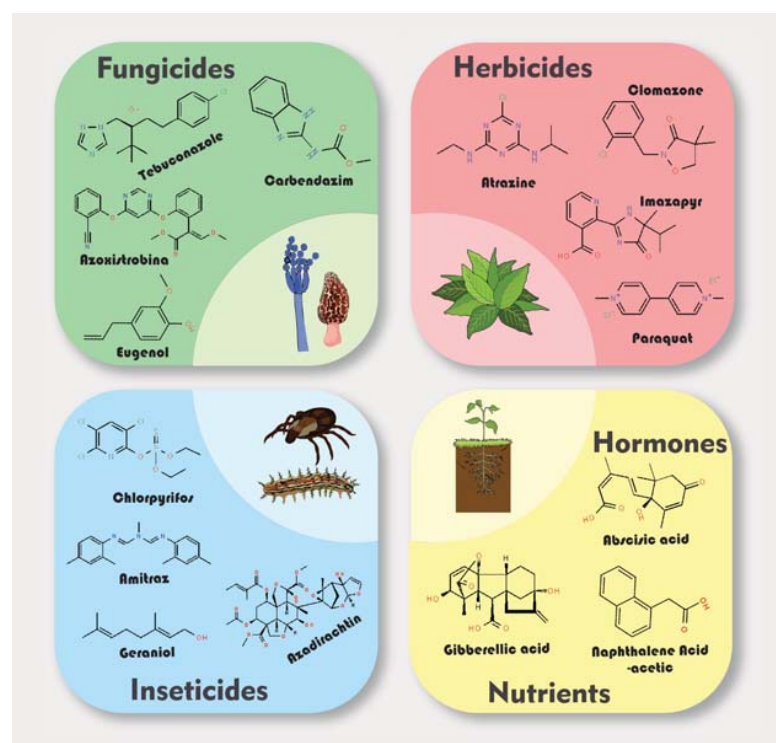

Fig. 2. Formulae of some active ingredients for agricultural applications 


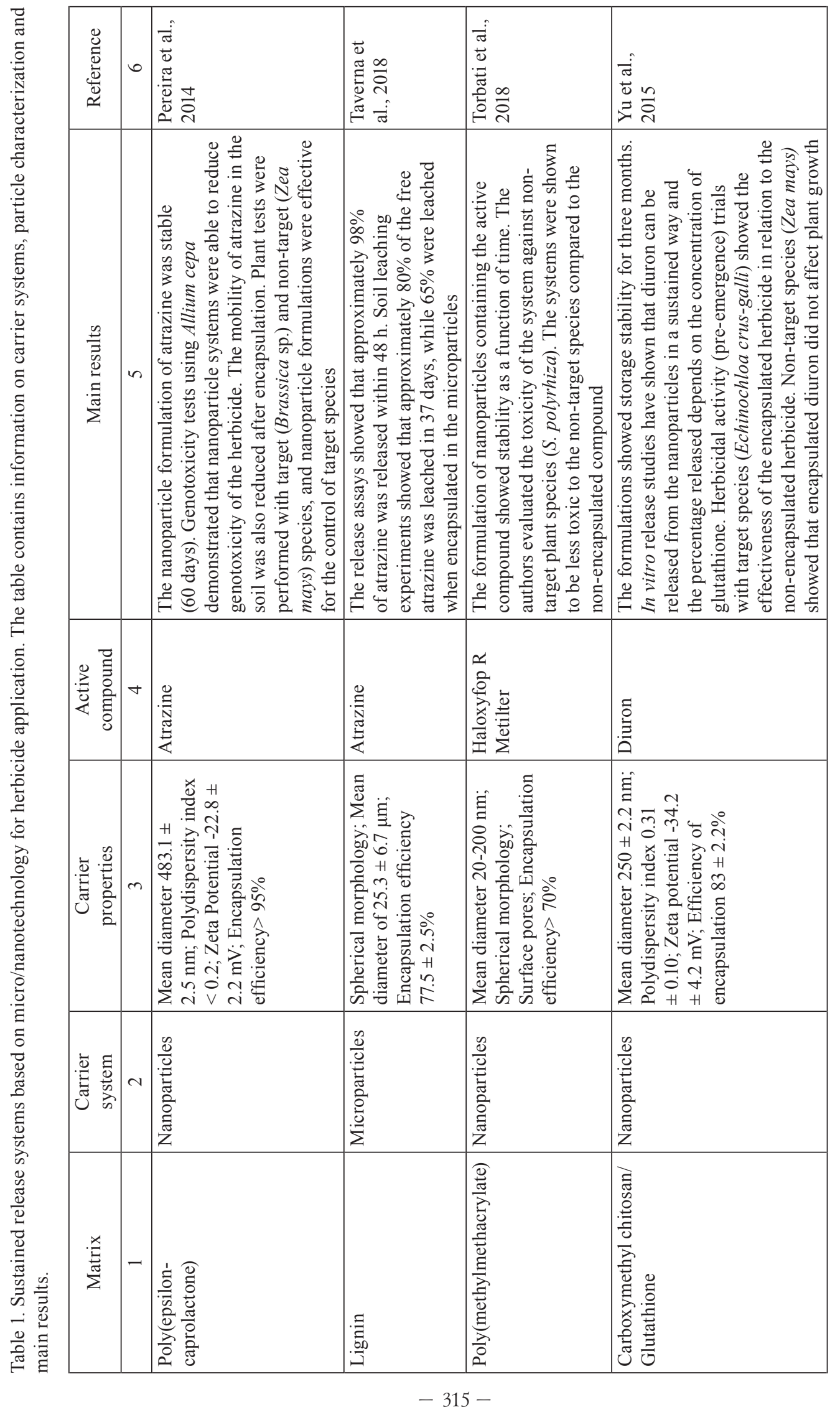




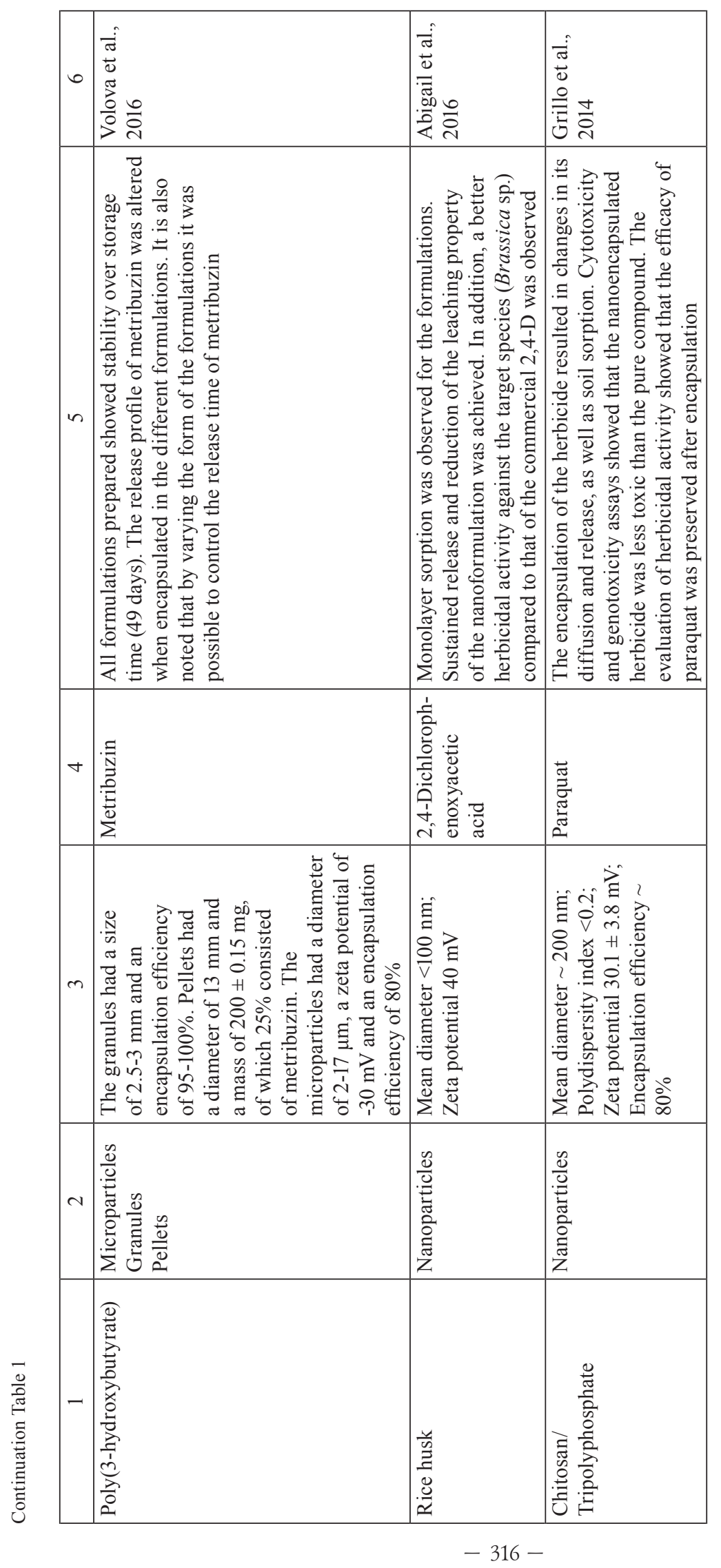


between $50 \%$ and $70 \%$; the nanoparticles had an average size of $400 \mathrm{~nm}$ and remained stable for 30 days at room temperature. Sustained release of the herbicides was observed, and the toxicity of the encapsulated herbicides was lower in comparison with the non-encapsulated herbicide.

In another study, Abigail et al. (2016) used rice husks to produce nanoparticles as a carrier for 2,4-D herbicides. The authors observed that due to the transformation of rice husks into particles of nanometric size, an increase in adsorption potential occurred. In addition, nanoformulations showed a higher herbicidal activity against the target plant Brassica sp. than commercial 2,4-D. The authors also observed a reduction in soil leaching after the encapsulation of herbicides.

Grillo et al. (2015) prepared polymeric nanoparticles of chitosan/tripolyphosphate loaded with herbicide paraquat and described their characteristics. They also investigated the effect of aquatic humic substances on the stability of nanoparticles and their toxicity to the environment. The results showed that the toxicity of paraquat was significantly reduced when the herbicide was encapsulated in nanoparticles, and the interaction of the nanoparticles with the humic substances also allowed a reduction of herbicide genotoxicity.

The search for new technologies for obtaining safer formulations of herbicides is important mainly due to the negative impacts of herbicides on the environment, including human health (workers, their families and consumers) and non-target species, such as pollinators. Because of the ease of application and the effectiveness of conventional herbicides, many farmers have abandoned more sustainable agricultural techniques. Thus, excessive use of herbicides puts human health at risk and interferes with the biological processes in ecosystems (Abouziena et al., 2016). In addition, such practices have led to the emergence of herbicide-resistant weeds, erosion and infertility of soils, and crop susceptibility to pathogens and diseases. Consequently, farmers use an increasing amount of herbicides to combat new pests. New technologies, such as nanotechnology, have been developed as tools to decrease the adverse effects of excessive herbicide application (Pérezde-Luque, 2017).

\section{Insecticides}

Insects are highly specialized animals that are easily adaptable to highly varied and harsh living conditions. They belong to the phylum Arthropoda, comprising more than one million described species (Rechcigl and Rechcigl, 2016). In agriculture, these organisms play an important role as pollinators, but they can also act as agricultural pests. Agricultural pests are one of the main factors in reducing crop productivity around the world. They can cause losses in the field and during storage (pre-harvest and postharvest losses) (Guedes et al., 2016).

Insecticides are currently the main means of controlling these organisms. They can fight adult insects as well as eggs and insect larvae (Mulé et al., 2017). Insecticides may have a synthetic or natural origin (when derived from secondary metabolites of plants). Throughout history, several types of natural materials have been used against insects, such as nicotine and tobacco (Oliveira et al., 2018). Insecticides can act through different mechanisms, such as inhibition of oviposition and feeding, promotion of mortality, and the induction of developmental disorders, and they also function as repellents (Mulé et al., 2017).

Although compounds with insecticidal activity are used to control diverse pests, their efficiency is decreasing due to developed resistance in pests caused by years of intensive use (Bass 


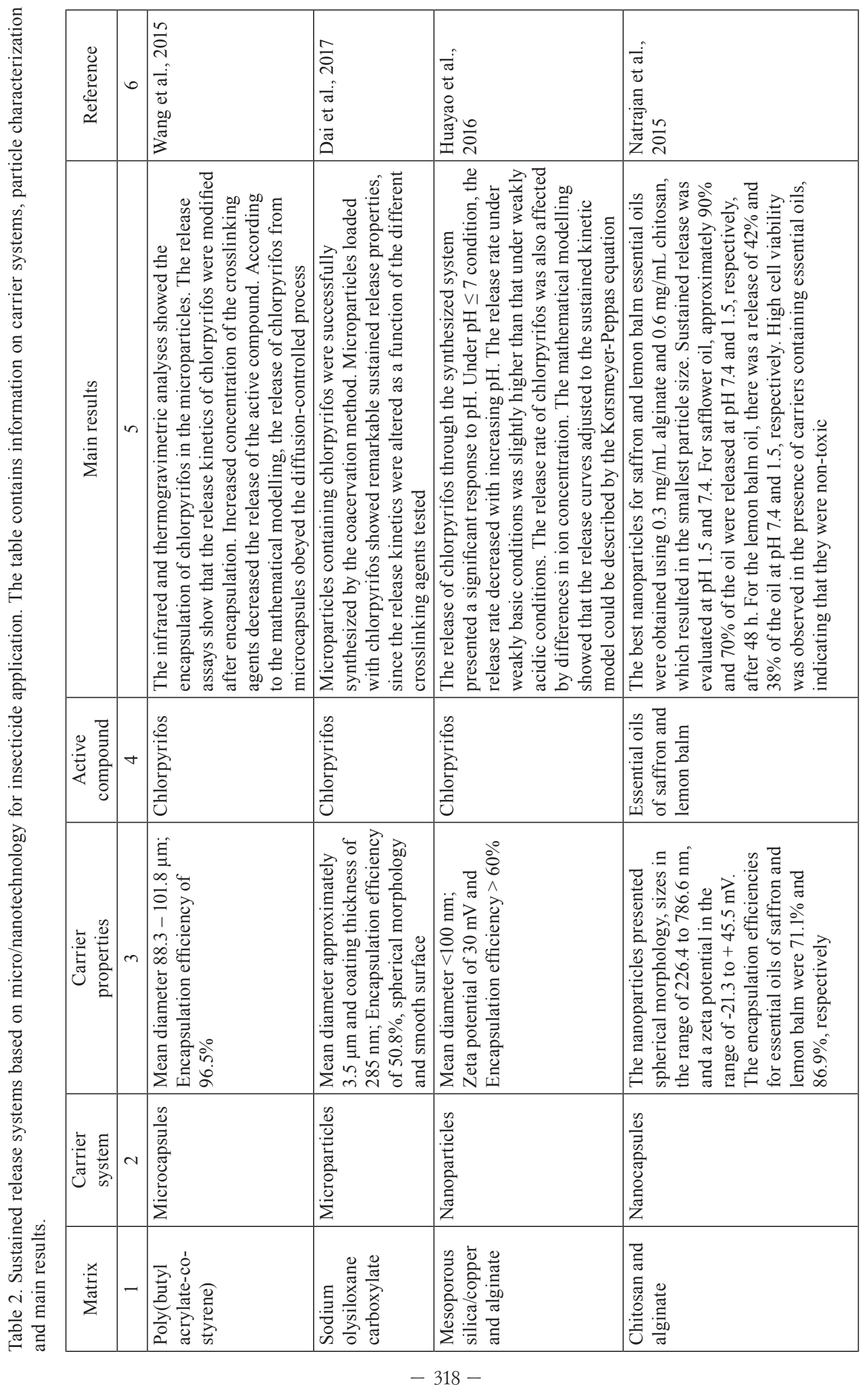




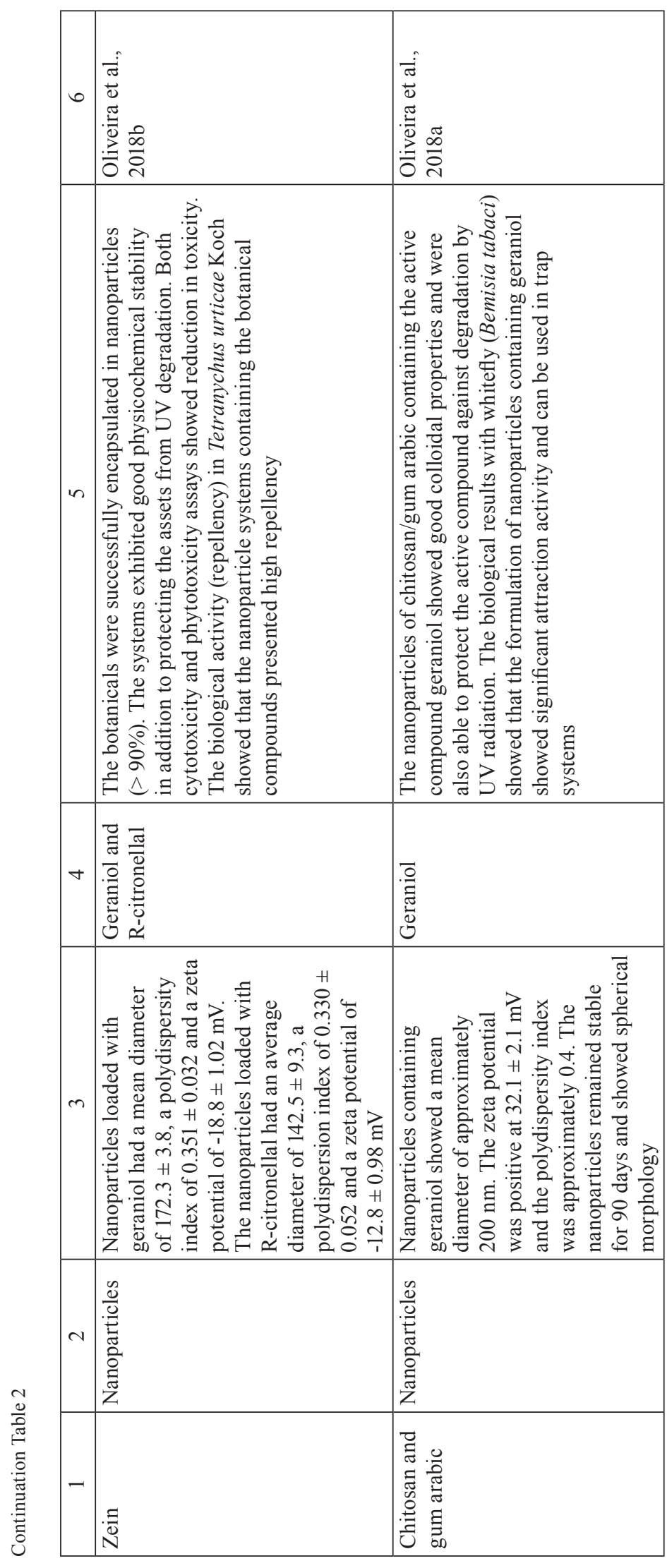


et al., 2015). Many conventionally formulated insecticides have several environmental incompatibilities (Moradi et al., 2019) and affect non-target organisms. They may exert toxic effects through different mechanisms of action and may even be lethal. There are reports on the negative impacts of insecticides on important species that collectively contribute to ecosystem integrity, such as pollinators, decomposers, and predators (Chagnon et al., 2015).

New strategies to circumvent pesticide resistance in harmful organisms to protect crops and improve vector control tools are invaluable to agriculture and public health. The use of compounds in a rotational approach is a more sustainable management practice of mitigating insecticide resistance and is, along with the minimization of chemical dependence and the development of eco-friendly technologies, one of the most favoured tactics (Bass et al., 2015). Table 2 provides references to a number of papers that describe nanotechnology-based carrier systems used for the application of insecticidal compounds.

The use of carrier systems improves insecticidal activity through targeted and sustained release of the active compound, as demonstrated in studies of formulations containing the $\lambda$-cyhalothrin pesticide (Zhang et al., 2019). Uniform particles of $800 \mathrm{~nm}$, a zeta potential of $+29.1 \mathrm{mV}$ and a loading efficiency of $31 \% \quad \lambda$-cyhalothrin were produced with dopamine-conjugated silica encapsulation. The sustained release from this system responded to $\mathrm{pH}$ variations with a higher percentage released in a more alkaline environment, which was in accordance with the Fickian diffusion model. The nanocapsules improved the stability of the pesticide, showed high activity against Helicoverpa armigera and reduced the genotoxicity of $\lambda$-cyhalothrin to non-target organisms.
Nanoparticles formed by encapsulation of the insecticides $\lambda$-cyhalothrin and imidacloprid in chitosan-coated nanoliposomes showed a positive surface charge $(\mathrm{ZP}=+31 \mathrm{mV})$, with a size of $69 \mathrm{~nm}$, a polydispersity index (PDI) of 0.25 and an encapsulation efficiency of $93 \%$ and $51 \%$, respectively (Moradi et al., 2019). The chitosan coating may aid in crossing through nonpolar substances, such as cuticular waxes and cellular membranes, and in the movement through polar substances such as water. The study showed that the concentration of chitosan influenced the thickness of the lipid layer, prolonged the residual activity of the insecticides and influenced the peak time of Myzus persicae mortality (Moradi et al., 2019).

In nanoparticle formulations with less stable active compounds, such as essential oils, the limiting characteristics of these compounds (degradation with UV light) can be circumvented, as is the case for the leaf oil of Zanthoxylum rhoifolium. The leaf oil was encapsulated in polycaprolactone (PCL) with 96\% efficiency, which gave rise to particles smaller than $500 \mathrm{~nm}$ with a zeta potential of $-20 \mathrm{mV}$ (Christofoli et al., 2015). The encapsulation promoted effective protection of the active ingredients against degradation with UV light, and their insecticidal effect on populations of Bemisia tabaci resulted in a $95 \%$ reduction in the number of eggs and nymphs. The release profile of the encapsulated insecticide was characterized by a rapid initial release followed by slow release for more than $12 \mathrm{~h}$.

\section{Hormones and nutrients}

Nutrients are chemical elements extracted by plants from the soil and water by absorption through roots. Nutrients are vital in metabolic processes to ensure satisfactory growth and productivity (Fageria, 2016). These compounds are divided into two main groups, macronutrients 


\begin{tabular}{|c|c|c|c|c|c|}
\hline 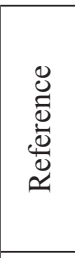 & 6 & 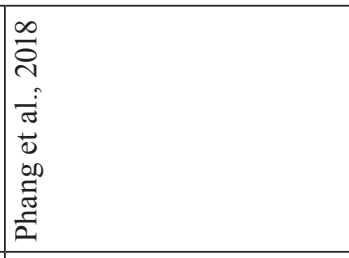 & 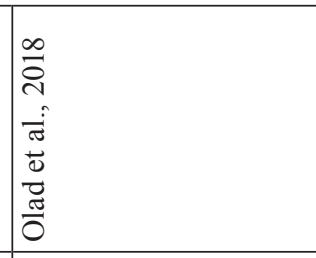 & 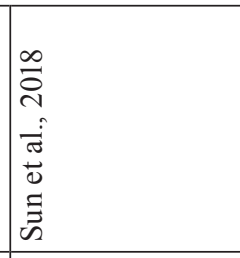 & 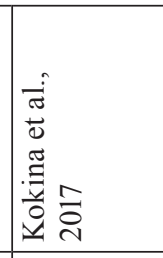 \\
\hline 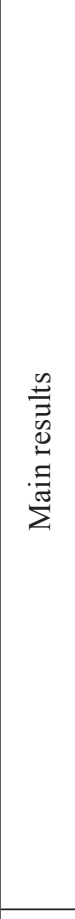 & n & 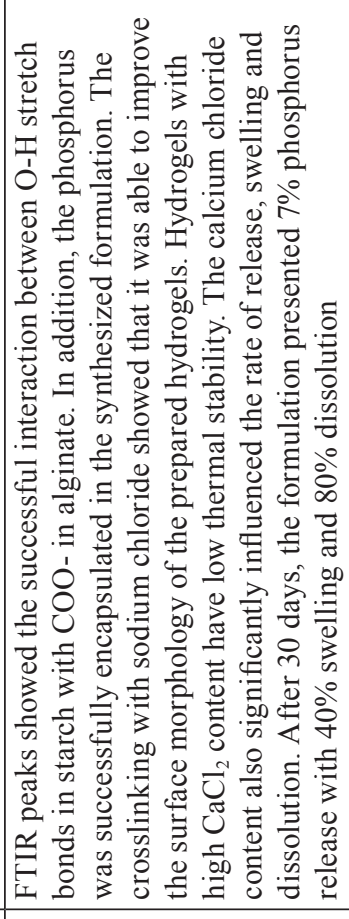 & 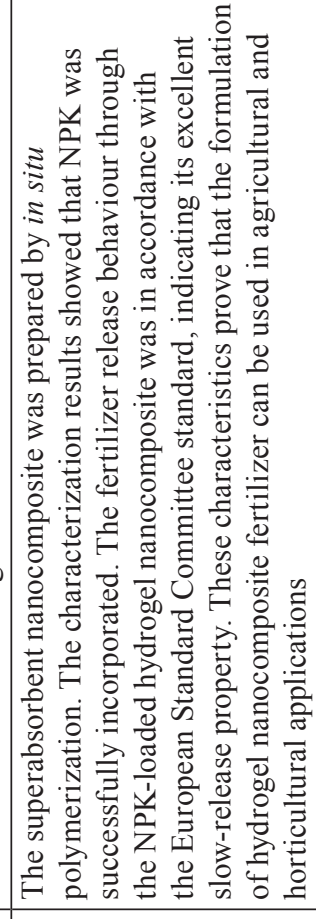 & 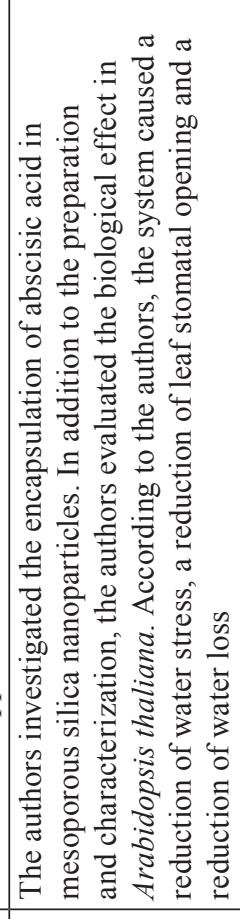 & 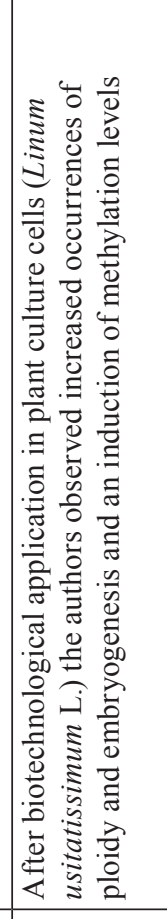 \\
\hline 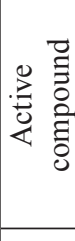 & + & \begin{tabular}{|l}
0 \\
$:$ \\
0 \\
0 \\
$\frac{1}{2}$ \\
0 \\
0 \\
$\frac{0}{2}$ \\
\end{tabular} & 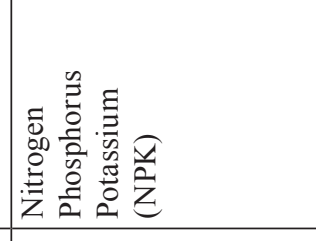 & 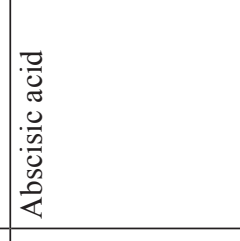 & 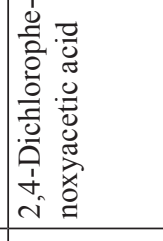 \\
\hline & & & 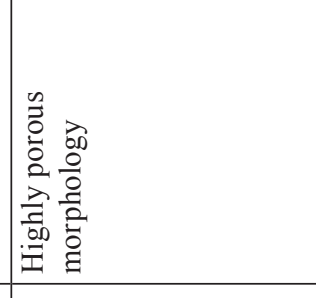 & 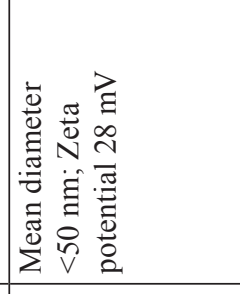 & 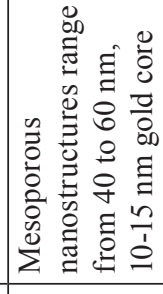 \\
\hline ". & N & 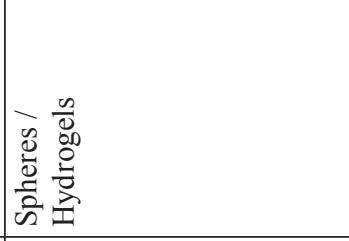 & 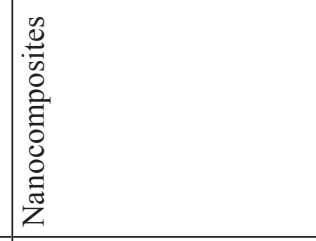 & 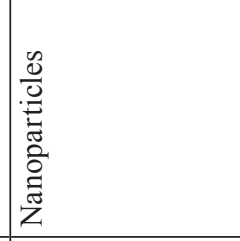 & 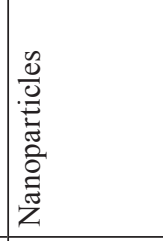 \\
\hline 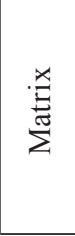 & - & 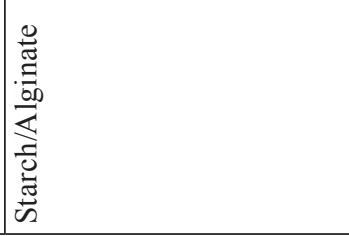 & 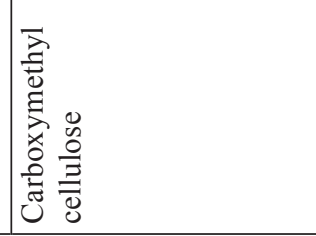 & 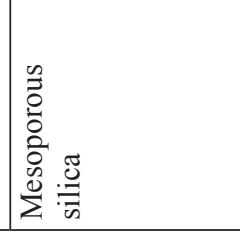 & 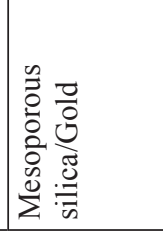 \\
\hline
\end{tabular}




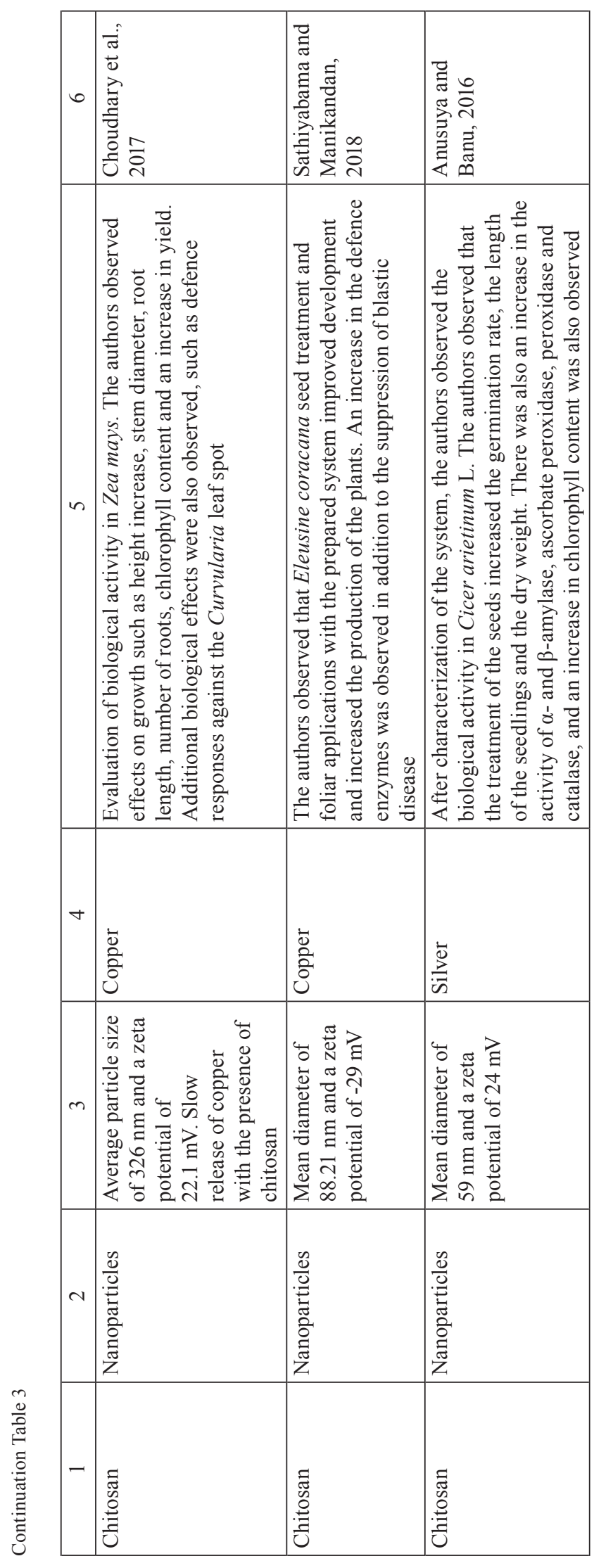


and micronutrients, which plants need at high and low concentrations, respectively. Macronutrients are major constituents of the most important plant substances; for example, phosphorus and nitrogen are essential components of nucleic acids (Xu, 2018). In contrast, plant hormones, or phytohormones, are natural substances of plant metabolism that regulate the physiological processes of growth and development (Ordaz-Ortiz et al., 2015). These molecules work as chemical messengers, transported from the production site to the target cells, and modulate gene expression and protein activity there (Khan et al., 2014). Table 3 presents some examples of studies that describe the encapsulation of hormones and nutrients in sustained release systems.

As shown in Table 3, different strategies have been employed to encapsulate plant fertilizers and hormones in an effort to control the release of nutrients into soil to promote plant growth, their resistance to unfavourable conditions and their protection from diseases. The use of chitosan as a matrix was investigated by different authors because it is known for its biocompatibility, biodegradability and economic viability (Anusuya and Banu, 2016; Choudhary et al., 2017; Sathiyabama and Manikandan, 2018). Choudhary et al. (2019) also used chitosan to synthesize zinc-chitosan nanoparticles to improve plant nutrition and development. The authors obtained highly bioactive positively charged nanoparticles with a spherical shape, porous structure and mean size of $387.7 \mathrm{~nm}$. A faster release was achieved at acidic pH (1 to 3), reaching $86.98 \%$ of zinc release after $144 \mathrm{~h}$. Znchitosan nanoparticles showed strong antifungal activity against Curvularia lunata and stimulated maize plant defence enzymes, increasing the activities of SOD (2.0-fold), PAL (3.0-fold), PPO and POD (up to $17.24-49.37 \%$ compared to that of the control). Seed and leaf treatments with the nanoparticles also increased plant height (1.3-1.6- fold), stem diameter (1.6-3.3-fold), root length (1.0-1.6-fold) and grain yield (by approximately $40 \%$ ). Chitosan was also successfully used in encapsulation of S-nitrosoglutathione (GSNO) by the ionotropic gelation method (Silveira et al., 2019). GSNO-chitosan nanoparticles had an average size of $104.8 \mathrm{~nm}$ and a positive zeta potential $(17.5 \mathrm{mV})$. These nanoparticles were efficient in controlling stress in sugarcane caused by water deficiency. Due to the controlled release features of nanoparticles, an increase in leaf $\mathrm{CO}_{2}$ assimilation was observed under the water deficit, as well as a 5.8-fold increase in shoot dry mass after encapsulated GSNO treatment when compared to that of the treatment with free GSNO.

Some studies have investigated the encapsulation of plant growth-promoting bacteria (PGPB) or rhizobacteria (PGPR). These microorganisms are responsible for plant stimulation through a wide variety of mechanisms, such as phosphate solubilization, nitrogen fixation and plant hormone production (Paul and Lade, 2014). Li et al. (2017) reported that the controlled release of bacterial fertilizers has a promising application in agroindustry. The authors produced microcapsules of Pseudomonas putida from a mixture of sodium alginate and bentonite using the external gelation technique. Spherical microcapsules ranging from 25 to $100 \mu \mathrm{m}$ with high encapsulation efficiency and yield of approximately $90 \%$ were obtained. In addition, the study showed that the matrix preserves cell viability under different $\mathrm{pH}$ conditions. He et al. (2017) showed that cotton seed treatment with sodium alginate-bentonite microcapsules loaded with Pseudomonas putida improved seed germination and plant development and efficiently alleviated salt stress at low salt concentrations $(0.5-1 \%)$.

Water, fertilizer deficit and other abiotic stresses are the main factors that limit plant 
growth and affect agricultural production worldwide (Silveira et al., 2019). Therefore, the development of environmentally friendly particles that could release nutrients slowly, reduce water consumption and increase crop yield is an emerging field extensively explored today. However, the wide production and commercialization of nanoparticles is still limited by certain obstacles (Mahanty et al., 2017; Choudhary et al., 2019), such as (i) the absence of well-developed techniques that are adaptable to large-scale commercial use for the production and application of biofertilizers, (ii) the lack of awareness of technology involved in nanoparticle products, especially among farmers, (iii) distrust of the formulations that do not pose any risks to the environment and health in both the general public and regulatory agencies worldwide, (iv) high costs of nanoparticle-based products having to compete with commercially available chemical products and (iv) insufficient knowledge of biofertilizer toxicity to the soil environment and the biofertilization interaction with soil microflora.

\section{Conclusion}

Nanotechnology is recognized as an important tool in the development of sustained release systems for agricultural applications. There is a large body of evidence that sustained release systems can be successfully employed to control agricultural pests as well as to improve plant nutrition and crop growth. However, there are still few commercial products available on the market. This is mainly due to the regulatory divergences that still exist in nanotech products as well as the scarcity of information regarding the relationship between the effectiveness of these new systems and their safety for nontarget organisms and the environment. Overall, this review summarizes works related to sustained release systems developed based on nanotechnology for agricultural applications. Part of the works reviewed presented systems as promising for use in agriculture without presenting the results on their biological activity. Despite this fact, in general, the review demonstrates that the use of nanotechnology allows the reduction of the amounts of active compounds used. It is also worth noting that nanoparticle-based products have high associated costs, so research is still needed to make them economically feasible with costs that are competitive with conventional formulations.

In conclusion, we emphasize that although a major breakthrough has been achieved in the field of nanoparticle-based formulation development for agricultural applications, further research is required to address the remaining gaps in technology.

\section{Acknowledgements}

The authors are grateful for the financial support provided by the São Paulo Research Foundation (FAPESP, grant \#2017/21004-5).

\section{References}

Abigail M.E.A., Samuel S.M., Chidambaram R. (2016) Application of rice husk nanosorbents containing 2,4-dichlorophenoxyacetic acid herbicide to control weeds and reduce leaching from soil. Journal of the Taiwan Institute of Chemical Engineers, 63: 318-326

Abouziena H.F., Haggag W.M. (2016) Weed control in clean agriculture: a review 1. Planta Daninha, 34(2): 377-392

Anusuya S., Banu K.N. (2016) Silver-chitosan nanoparticles induced biochemical variations of chickpea (Cicer arietinum L.). Biocatalysis and Agricultural Biotechnology, 8: 39-44 
Bass C., Denholm I., Williamson M.S., Nauen R. (2015) The global status of insect resistance to neonicotinoid insecticides. Pesticide Biochemistry and Physiology, 121: 78-87

Bruinsma J. (2017) World agriculture: towards 2015/2030: an FAO study. Routledge

Chagnon M., Kreutzweiser D., Mitchell E.A., Morrissey C.A., Noome D.A., Van der Sluijs J.P. (2015) Risks of large-scale use of systemic insecticides to ecosystem functioning and services. Environmental Science and Pollution Research, 22(1): 119-134

Choudhary R.C., Kumaraswamy R.V., Kumari S., Sharma S.S., Pal A., Raliya R., Biswas P., Saharan V. (2017) Cu-chitosan nanoparticle boost defense responses and plant growth in maize (Zea mays L.). Scientific Reports, 7: 9754

Choudhary R.C., Kumaraswamy R.V., Kumari S., Sharma S.S., Pal A., Raliya R., Biswas P., Saharan V. (2019) Zinc encapsulated chitosan nanoparticle to promote maize crop yield. International Journal of Biological Macromolecules, 127: 126-135

Christofoli M., Costa E.C.C., Bicalho K.U., Domingues V.C., Peixoto M.F., Alves C.C.F., Araújo W.L., Cazal C.M. (2015) Insecticidal effect of nanoencapsulated essential oils from Zanthoxylum rhoifolium (Rutaceae) in Bemisia tabaci populations. Industrial Crops and Products, 70: 301-308

Cobb A.H., Reade J.P.H. (2010) Herbicides and plant physiology. Oxford, UK, Wiley-Blackwell

Dai R.Y., You S.Y., Lu L.M., Liu Q., Li Z.X., Wei L., Huang X.G., Yang Z.Y. (2017) High blades spreadability of chlorpyrifos microcapsules prepared with polysiloxane sodium carboxylate/sodium carboxymethylcellulose/gelatin via complex coacervation. Colloids and Surfaces A: Physicochemical and Engineering Aspects, 530: 13-19

Fageria N.K. (2016) The use of nutrients in crop plants. CRC Press

Fraceto L.F., Grillo R., De Medeiros G.A., Scognamiglio V., Rea G., Bartolucci C. (2016) Nanotechnology in agriculture: which innovation potential does it have? Frontiers in Environmental Science, 4: 20

Grillo R., Clemente Z., Oliveira J.L. de, Campos E.V.R., Chalupe V.C., Jonsson C.M., Lima R. de, Sanches G., Nishisaka C.S., Rosa A.H., Oehlke K., Greiner R., Fraceto L.F. (2015) Chitosan nanoparticles loaded the herbicide paraquat: the influence of the aquatic humic substances on the colloidal stability and toxicity. Journal of Hazardous Materials, 286: 562-572

Guedes R.N.C., Smagghe G., Stark J.D., Desneux N. (2016) Pesticide-induced stress in arthropod pests for optimized integrated pest management programs. Annual Review of Entomology, 61: 43-62

He X., Deng H., Hwang H. (2019) The current application of nanotechnology in food and agriculture. Journal of Food and Drug Analysis, 27(1): 1-21

He Y., Wu Z., Tu L., Shan C. (2017) Effect of encapsulated pseudomonas putida Rs-198 strain on alleviating salt stress of cotton. Journal of Plant Nutrition, 40(8): 1180-1189

Huayao C., Yueshun L., Hongjun Z., Xinhua Z., Sheng G., Hua X. (2016) Highly efficient alginate sodium encapsulated chlorpyrifos/copper(II) Schiff base mesoporous silica sustained release system with $\mathrm{pH}$ and ion response for pesticide delivery. RSC Advances, 6(115): 114714-114721

Khan M., Rozhon W., Poppenberger B. (2014) The role of hormones in the aging of plants - a mini-review. Gerontology, 60(1): 49-55

Kokina I., Jahundoviča I., Mickeviča I., Jermaļonoka M., Strautiņ̌̌ J., Popovs S., Ogurcovs A., Sledevskis E., Polyakov B., Gerbreders V. (2017) Target transportation of auxin on mesoporous Au/ 
$\mathrm{SiO} 2$ nanoparticles as a method for somaclonal variation increasing in flax (L. usitatissimum L.). Journal of Nanomaterials: 7143269

Kremer R.J. (2019) Chapter 15 - Bioherbicides and nanotechnology: current status and future trends. Nano-biopesticides today and future perspectives. Koul O. (ed.) Academic Press, p. 353-366

Li X., Wu Z., He Y., Ye B., Wang J. (2017) Preparation and characterization of monodisperse microcapsules with alginate and bentonite via external gelation technique encapsulating Pseudomonas putida Rs-198. Journal of Biomaterials Science, Polymer Edition, 28(14): 1556-1571

Mahanty T., Bhattacharjee S., Goswami M., Bhattacharyya P., Das B., Ghosh A., Tribedi P. (2017) Biofertilizers: a potential approach for sustainable agriculture development. Environmental Science and Pollution Research, 24(4): 3315-3335

Maruyama C.R., Guilger M., Pascoli M., Bileshy-José N., Abhilash P.C., Fraceto L.F., Lima R. De. (2016) Nanoparticles based on chitosan as carriers for the combined herbicides imazapic and imazapyr. Scientific Reports, 6: 19768

Moradi F.G., Hejazi M.J., Hamishehkar H., Enayati A.A. (2019) Co-encapsulation of imidacloprid and lambda-cyhalothrin using biocompatible nanocarriers: characterization and application. Ecotoxicology and Environmental Safety, 175: 155-163

Mulé R., Sabella G., Robba L., Manachini B. (2017) Systematic review of the effects of chemical insecticides on four common butterfly families. Frontiers in Environmental Science, 5: 32

Natrajan D., Srinivasan S., Sundar K., Ravindran A. (2015) Formulation of essential oil-loaded chitosan-alginate nanocapsules. Journal of Food and Drug Analysis, 23(3): 560-568

Olad A., Zebhi H., Salari D., Mirmohseni A., Reyhani Tabar A. (2018) Slow-release NPK fertilizer encapsulated by carboxymethyl cellulose-based nanocomposite with the function of water retention in soil. Materials Science and Engineering: C, 90: 333-340

Oliveira J.L. de, Campos E.V.R., Fraceto L.F. (2018) Recent developments and challenges for nanoscale formulation of botanical pesticides for use in sustainable agriculture. Journal of Agricultural and Food Chemistry, 66(34): 8898-8913

Oliveira J.L. de, Campos E.V.R., Pereira A.E.S., Nunes L.E.S., Silva C.C.L. Da, Pasquoto T., Lima R., Smaniotto G., Polanczyk R.A., Fraceto L.F. (2018a) Geraniol encapsulated in chitosan/gum arabic nanoparticles: a promising system for pest management in sustainable agriculture. Journal of Agricultural and Food Chemistry, 66(21): 5325-5334

Oliveira J.L. de, Campos E.V.R., Pereira A.E.S., Pasquoto T., Lima R., Grillo R., Andrade D.J. de, Santos F.A.D., Fraceto L.F. (2018b) Zein nanoparticles as eco-friendly carrier systems for botanical repellents aiming sustainable agriculture. Journal of Agricultural and Food Chemistry, 66(6): 13301340

Ordaz-Ortiz J.J., Foukaraki S., Terry L.A. (2015) Assessing temporal flux of plant hormones in stored processing potatoes using high definition accurate mass spectrometry. Horticulture Research, 2: 15002

Paul D., Lade H. (2014) Plant-growth-promoting rhizobacteria to improve crop growth in saline soils: a review. Agronomy for Sustainable Development, 34(4): 737-752

Pereira A.E.S., Grillo R., Mello N.F.S., Rosa A.H., Fraceto L.F. (2014) Application of poly(epsiloncaprolactone) nanoparticles containing atrazine herbicide as an alternative technique to control weeds and reduce damage to the environment. Journal of Hazardous Materials, 268: 207-215 
Pérez-De-Luque A. (2017) Interaction of nanomaterials with plants: what do we need for real applications in agriculture? Frontiers in Environmental Science, 5: 12

Phang S.W., Low J.Y., Tee T.-T. (2018) Release behaviour study on controlled-release phosphorous fertilizer encapsulated by starch - alginate superabsorbent composite. Journal of Engineering Science and Technology, 13(Special Issue 7): 82-94

Prosser R.S., Anderson J.C., Hanson M.L., Solomon K.R., Sibley P.K. (2016) Indirect effects of herbicides on biota in terrestrial edge-of-field habitats: a critical review of the literature. Agriculture, Ecosystems \& Environment, 232: 59-72

Rechcigl J.E., Rechcigl N.A. (2016) Insect pest management: techniques for environmental protection. CRC Press

Sathiyabama M., Manikandan A. (2018) Application of copper-chitosan nanoparticles stimulate growth and induce resistance in finger millet (Eleusine coracana Gaertn.) plants against blast disease. Journal of Agricultural and Food Chemistry, 66(8): 1784-1790

Shiva V. (2016) The violence of the green revolution: third world agriculture, ecology, and politics. University Press of Kentucky

Shukla P., Chaurasia P., Younis K., Qadri O.S., Faridi S.A., Srivastava G. (2019) Nanotechnology in sustainable agriculture: studies from seed priming to post-harvest management. Nanotechnology for Environmental Engineering, 4: 11

Silveira N.M., Seabra A.B., Marcos F.C.C., Pelegrino M.T., Machado E.C., Ribeiro R.V. (2019) Encapsulation of S-nitrosoglutathione into chitosan nanoparticles improves drought tolerance of sugarcane plants. Nitric Oxide, 84: 38-44

Sun D., Hussain H.I., Yi Z., Rookes J.E., Kong L., Cahill D.M. (2018) Delivery of abscisic acid to plants using glutathione responsive mesoporous silica nanoparticles. Journal of Nanoscience and Nanotechnology, 18(3): 1615-1625

Taverna M.E., Busatto C.A., Lescano M.R., Nicolau V.V., Zalazar C.S., Meira G.R., Estenoz D.A. (2018) Microparticles based on ionic and organosolv lignins for the controlled release of atrazine. Journal of Hazardous Materials, 359: 139-147

Torbati S., Mahmoudian M., Alimirzaei N. (2018) Nanocapsulation of herbicide Haloxyfop-Rmethyl in poly(methyl methacrylate): phytotoxicological effects of pure herbicide and its nanocapsulated form on duckweed as a model macrophyte. Turkish Journal of Chemistry, 42(1): 132-145

Volova T., Zhila N., Vinogradova O., Shumilova A., Prudnikova S., Shishatskaya E. (2016) Characterization of biodegradable poly-3-hydroxybutyrate films and pellets loaded with the fungicide tebuconazole. Environmental Science and Pollution Research, 23(6): 5243-5254

Wang Y., Gao Z., Shen F., Li Y., Zhang S., Ren X., Hu S. (2015) Physicochemical characteristics and slow release performances of chlorpyrifos encapsulated by poly(butyl acrylate- co -styrene) with the cross-linker ethylene glycol dimethacrylate. Journal of Agricultural and Food Chemistry, 63(21): $5196-5204$

Xu G. (2018) Sensing and transport of nutrients in plants. Seminars in Cell \& Developmental Biology, 74: 78-79

Yu Z., Sun X., Song H., Wang W., Ye Z., Shi L., Ding K. (2015) Glutathione-responsive carboxymethyl chitosan nanoparticles for controlled release of herbicides. Materials Sciences and Applications, 6(6): 591-604 
Zhang W., Tang G., Dong H., Geng Q., Niu J., Tang J., Yang J., Huo H., Cao Y. (2019) Targeted release mechanism of $\lambda$-cyhalothrin nanocapsules using dopamine-conjugated silica as carrier materials. Colloids and Surfaces B: Biointerfaces, 178: 153-162

Zimdahl R.L. (2018) Chapter 14. Herbicides and plants. Fundamentals of weed science. Fifth edition. Academic Press, p. 417-443 